\title{
Nursing Succession Planning-Mental Health Center Case Study
}

\author{
Isaak $\mathrm{V}^{1 *}$, Steiner- Lavi $\mathrm{O}^{1}$, Kostisky $\mathrm{H}^{2}$, Bar-Noy $\mathrm{D}^{2}$, and Makori $\mathrm{S}^{2}$ \\ ${ }^{1}$ Management Faculty, MLA College for Academic Studies, Israel. \\ ${ }^{2}$ Sha'ar-Menashe Mental Health center, Israel. \\ *Correspondence to: Valerie Isaak, Management Faculty, MLA College for Academic Studies, Israel; Tel: +972 526095117; Fax +972 (3) 7354445; \\ Email: valerie_i@mla.ac.il.
}

Received: September 10, 2017; Accepted: November 28, 2017; Published: December 07, 2017;

\begin{abstract}
This article presents the process of developing a managerial development succession plan in nursing, as developed at a mental health hospital. There is a shortage of comprehensive and systematic research on the integration of the nursing sector in management positions at the hospital and the public sector. In light of the above, a managerial succession plan was developed for the hospital nursing staff. Participants took part in the program until their eventual placement in managerial positions model till the affiliation of managerial positions. The process is highly recommended for other hospitals or organizations in the public sector.
\end{abstract}

Key Words: Managerial succession planning, Psychiatric hospitals, Public sector

\section{Introduction}

Managerial succession planning is a mean for achieving high performance, filling key positions and meeting current and future talent needs [1]. To meet this goal, organizations must develop formal programs to enable a core managerial succession plan for their organizational activity [2].

Studies demonstrate the importance of developing a managerial succession plan in general and specifically a nursing succession plan [3]. The critics argue that there is a lack of essential knowledge and skills required for a management position [4]. This is crucial in nursing, as the transition from a nursing to a managerial position involves the integration of leadership and managerial skills that were not part of their daily routine $[5,6]$. These employees are required to commit to the organization's goals, technology and management challenges [7]. Managerial positions require the development of appropriate skills that will help meet management challenges along with the challenges of nursing [8]. They further require the acquisition of communication skills, flexibility, adaptability and commitment to strategy [9], human resources skills and political wisdom which are all essential to effective management in the field of nursing [10].

Promoting untrained employees to managerial positions may cause organizational and personal damage such as a decrease in employee motivation, stress and burnout, dysfunction and a lack of organizational effectiveness [11]. To reduce negative impacts, organizations recruit candidates for managerial succession and prepare them for management positions in a structured program [3].

The Robert Wood Johnson Foundation developed a management program for nurses. It was developed in the United States and intended to guide, develop and train nurses to cope with the challenges of the future [12]. This leadership training was intended for nurses who served in senior management positions in hospitals and clinics in order to improve their managerial skills. There was no emphasis on preparation for junior managerial positions or to succession planning.

In nursing, employees are promoted to managerial positions based on intuition or objective constraints without proper training [3]. In fact, until 2012, there was no relevant training for junior level managers nor was there a succession planning program for the nursing sector.

\section{Case Study}

Considering the inconsistency of the process in the field of nursing, we found it appropriate to deal with this issue in terms of human resource development processes in hospitals. Since there is no training track for succession planning in nursing, such a track was developed at a mental health hospital. The program was based on stages of location, training and placement in nursing managerial positions.

A comprehensive managerial program was formulated in order to locate candidates, train them in the managerial track and placing them in management positions. The program included a number of stages, as detailed below.

\section{Candidate location:}

The first stage entailed building a process for locating candidates. The main principles were transparency and fairness. The process was as follows:

- Call for candidates,

- Requesting supervisors to identify committed employees, 
- Candidate files,

- Assessment interview,

- Acceptance/rejection letter.

After formulating the main idea of the nursing succession plan in the hospital, a call for candidates was published through all internal communication channels at the hospital, describing the assessment process to the candidates. The department heads were provided an explanation of the process and their possible contribution. Those responsible supervisors were asked to locate candidates in their departments and to encourage them to apply. The candidate portfolio consisted of a supervisor recommendation based on a structured form built by the steering committee. The supervisors were asked to explain their choice of candidates, emphasizing clinical and managerial skills. The employee evaluation form was attached as well.

The steering committee met and reviewed the candidates' portfolios based on pre-determined criteria, rating each aspect on a scale. The candidates were invited for a personal interview with the steering committee. At the end of the interview, each member of the steering committee rated the candidate and a final grade was determined after discussion. Applicants with high scores were accepted to the course. The rejected candidates were given an explanation for their rejection.

\section{Building a training program}

In the second phase, a training program was constructed. The program focused on clinical and managerial skills.

The clinical skills taught throughout the course included communication with families, legal formulation of administrative records, rehabilitation and innovative treatment methods geared toward psychiatric hospital implementation.

The managerial skills were leadership, teamwork, decision-making and creativity.

The candidates worked on self-analysis and building a program for personal and professional development. Each candidate received feedback on his personal development throughout the course.

The training program was conducted through multiple learning strategies, ranging from ODT (Outdoor Training) to lectures, workshops, questionnaires, self-analysis tools, peer learning, project preparation and simulations. The training processes focused on the self-development of each candidate regarding his strengths and weaknesses.

One of the course requirements, which was an indicator of whether or not to promote the employee to a managerial position, was to lead an improvement project in the department or hospital. The team project aimed to improve department performance and thus improve hospital performance. The participants select a relevant topic from a range of hospital activities. The teams received academic and clinical support during the preparation of the projects. The projects were presented as part of a seminar on the final day of the course.

\section{Assigning employees to management positions}

The third phase, at the end of the course, was based on an evaluation prepared for each participant. It presented the development process throughout the course, the skills developed and the skills requiring further development. All candidates were invited to a personal interview with the Nursing Director. The candidate was presented with feedback on his performance as well as a decision regarding his professional career in the hospital. Some of the candidates were immediately assigned to junior management positions at the hospital, some were notified of future promotions, while the others were assigned to continuous training on a personal level.

\section{Evaluation, feedback and building a continuous plan}

In the final phase, as part of the steering committee's learning curve, all participants were subject to an assessment and evaluation process in terms of training program, its contents and future development. The feedback demonstrated an expectation for a continuation course which would place an emphasis on communication skills, conflict management, and teamwork with a supervisor and project leadership.

A follow-up program is currently being prepared, as part of a continuously learning process.

\section{Discussion}

Succession planning is a central organizational process that seeks to achieve long-term effectiveness by ensuring the recruitment of employees who will be able to fulfil managerial positions in their organization. There is no structured process for identifying, developing and placing employees in nursing managerial positions. This paper presents a model developed by the authors, which was implemented as a pilot in one of the largest psychiatric hospitals in Israel. Despite initial apprehension of this new process (both managers and employees), the candidates completed the program. Within two years, half were appointed to managerial positions as deputy heads of various departments, others were promoted to supervisory roles, coordinating the accreditation and quality of the hospital. Feedback compiled after several years demonstrates high motivation to fulfill the role successfully and to contribute in other areas (such as research, improvement teams).

\section{Conclusion}

To conclude, the goal of setting a succession planning program was achieved. A precedent was set in the hospital at the organizational level as well as in the sectoral level for succession planning. The entire process aroused great interest among all employees, even from other sectors, awarding prestige to those chosen for the program. The process shows that it is possible to rise above prejudicial stigmas about employees who work in the organization for decades. It is possible to develop a structured and professional succession program for the next managerial generation that will lead the hospital to a high level of performance. It appears that the process, in its current format, has succeeded and should be expanded to other hospitals in the future.

\section{References}

1. Rothwell WJ (2010). Effective Succession Planning: Ensuring Leadership Continuity and Building Talent from Within ( $4^{\text {th }}$ edn). New York, Amacom, USA.

2. Santora JC, Sarros JC, Bozer G, Esposito M, Bassi A (2015) Nonprofit Executive Succession Planning and Organizational Sustainability A Preliminary Comparative Study in Australia, Brazil, Israel, Italy, Russia, and the United States. J Appl Manag Entrep 20: 66-83. 
3. Toren A (2009) leadership in with-managing Nurse in Hospitals. Jerusalem, Magnes, Israel.

4. Salmon ME, Rambo K (2002) Government Chief Nursing Officers: a study of the key issues they face and the knowledge and skills required by their roles. Int Nurs Rev 49: 136-143. [crossref]

5. Melina LR, Burgess GJ, Falkman LL, Marturano A (2013) The Embodiment of Leadership. San Francisco, Jossey-Bass, USA.

6. Grossman SC, Valiga TM (2013) The New Leadership Challenge: Creating the Future of Nursing ( $4^{\text {th }}$ edn). Philadelphia, FA Davis, USA.

7. Eneh VO, Vehvilainen-Julkunen K, Kvist T (2012) Nursing leadership practices as perceived by Finnish nursing staff: high ethics, less feedback and rewards. J Nurs Manag 20: 159-169. [crossref]
8. McGuire E, Kennerly SM (2006) Nurse Managers as transformational and transactional leaders. Nurs Econ 24: 179-185, 175. [crossref]

9. Carney M (2004) Middle manager involvement in strategy development in notfor profit organizations: The director of nursing perspective - How organizational structure impacts on the role. J Nurs Manag 12: 13-21. [crossref]

10. Kirk H (2009) Factors identified by Nurse Executive Directors as important to their success. J Nurs Manag 17: 956-964. [crossref]

11. Rothwell WJ (2002) Putting Success into Your Succession Planning. J Bus Strategy 23: 32-37.

12. Morjikian R, Bellack J (2005) The RWJ Executive Nurse Fellows Program, Part 1: Leading change. J Nurs Adm 35: 431-438. [crossref]

\section{Citation:}

Isaak V, Steiner- Lavi O, Kostisky H, Bar-Noy D, and Makori S (2017) Nursing Succession Planning-Mental Health Center Case Study. Ageing Sci Ment Health Stud Volume 1(2): 1-3 